\title{
ハイビジョン立体撮影による耳手術供覧
}

八木 聰明・斉藤 博*

\section{Demonstration of Ear Surgery by 3-D Hi-Vision System}

Toshiaki Yagi

(Nippon Medical School)

Hiroshi Saito

(Nagashima Medical Instruments Co.)

3-D Hi-Vision system is introduced for otomicrosurgery. One patient with otosclerosis was operated on under microscopy and a Hi-Vision camera. The surgical procedure was recorded by a recently developed 3-D Hi-vision camera. This system provides images of superior quality and 3-D view with a greater resolution than ordinary video systems.

Key words: $3-\mathrm{D}, \mathrm{Hi}-\mathrm{Vision}$, otosclerosis, video

\section{はじめに}

医学教育，とくに卒後教育に括ける視覚材料 の利用は，その教育効果を上げるらえにも極め て有用である。その中でも内視鏡, あるいは顕 微鏡を用いた手術の状況をビデオ画像を通して， on-line あるいは off-line で多くの人に供覧する ことは，現在最も広く用いられている方法であ る.この方法には多くの長所があるが，短所が ないわけではない，その少ない短所の中で最む 大さなものは，特に顕微鏡を用いた手術の場合， 術者が実際に見ているのは立体像であるにもか かわらずビデオ画像は 2 次元平面であり, 立体 感は自分の解剖学的知識や経験から構築しなく てはならない点である.この短所は中耳や内耳 の手術の理解といら点からは大きな問題であり, これを解決することは教育を含め極めて重大な 意味をもっている。
一方最近, テレビの撮影や再生技術の向上に 目を見晴らせるものがあるが，ハイビジョンも その 1 つである. 走査線の数が従来型 NTSC (National Television System Committee) 方式 テレビ(525本)の倍以上 $(1,125$ 本)あり, 高画質 映像を提供してくれる.

今回, ハイビジョンと立体撮影という $2 つ の$ 要素を組み合わせた方式で, 顕微鏡下の耳手術 (アブミ骨手術)を記録したので, その方法や実 際の記録, 画面再生, 教育上の効果について報 告する.

\section{方法}

八イビジョン立体撮影は, 日本医科大学付属 病院中央手術部の耳鼻咽喉科手術室に設置され た手術用双眼顕微鏡 (永島医科器械製)を用いて 行った. 撮影は, 双眼顕微鏡の立体視用の左右 の視野から得られた画像を本目的のために開発

* 永島医科器械株式会社 
された導出装置で顕微鏡本体上に取付けた軽量 のハイビジョンカメラに左右同時に導くもので ある(図 1 )。本装置は，カメラと左右の画像を 導出する装置を合せて $1.9 \mathrm{Kg}$ と軽量であり， 手術中の顕微鏡操作に全く支障はない. 左右の 視野から得られたそれぞれの映像は，ハイビジ ョンの縦横比が従来型テレビ $(3: 4)$ と異なり横 長 $(9: 16)$ である特長も利用して, 同一画面に 入力される。すなわち，八イビジョン画像の左 半分に術者の左目で見たのと同じ画像が，右半 分に術者の右目で見たのと同じ画像が録画され ることになる。したがって，このモ二タ一画面 を立体視のできる人は直接，できない人では立 体視用の眼鏡を掛けて見れば立体画像を見るこ とができる。

\section{症例と結果}

症例 : 23歳, 男性.

主訴：両側難聴.

現病歷 : 約 3 年前から両側難聴(特に左が強 い)と耳鳴を自覚した。難聴は徐々に進えでい るように感じていた。

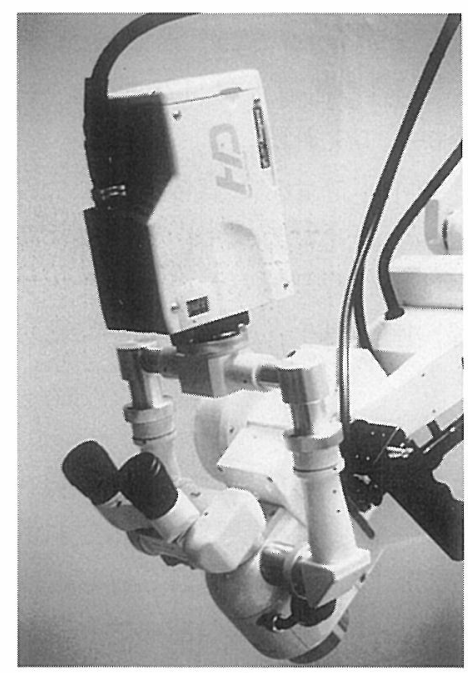

図 1 手術用双眼顕微鏡 (永島医科器械製) に 取付けられた立体ハイビジョンカメラ
現症: 両側鼓膜は正常であり, 他の耳鼻咽喉 科的所見にも異常はみられない. 純音聴力検査 結果は会話域 3 分法で, 左右の気導聴力レベル はそれぞれ $55.0 \mathrm{~dB}$ と $45.0 \mathrm{~dB}$ ，骨導のそれは それぞれ $28.3 \mathrm{~dB}$ と $23.3 \mathrm{~dB}$ であった。ティ ンパノグラムは左右ともAs 型であった。病歴 と所見から耳硬化症と診断し，全身麻醉下に左 のアブミ骨手術を行った.

手術は耳後切開で行い, 外耳道皮膚に連続し て鼓膜後部を挙上し，キヌタ・アブミ関節，ア ブミ骨底板，顔面神経管を明視下に拈いた(図
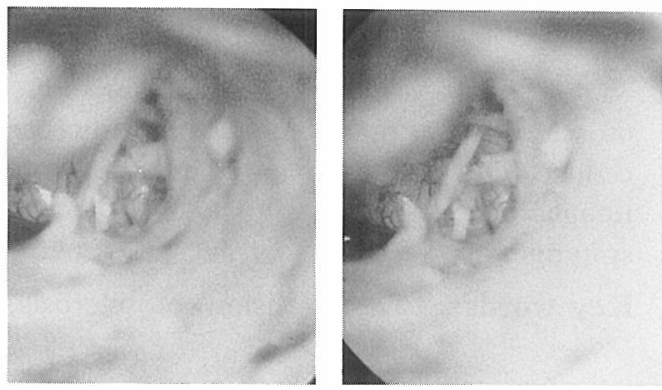

図 2 鼓室を開放し, 鼓索神経, キヌタ骨, アブ ミ骨，アブミ骨筇腱，顔面神経管，正円空 窩を明視下に扣いたところ。

(ハイビジョン映像をデジタル画像処理システムに よりデータ変換し, 直接印刷したもので, 縦 : 横 比が $9: 16$ で実際のハイビジョンの画面比に等し い.この画像はテレビ画面と同様に立体視ができ る(平行視). 図 3,4 8同様. な招, 本画像の才 リジナルに関しては,大日本印刷の提供を受けた。
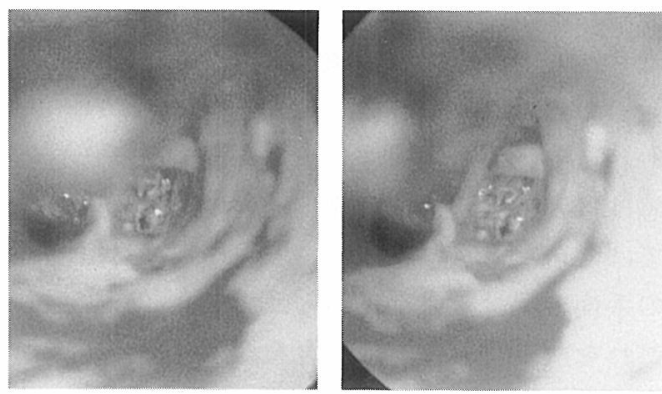

図 3 アブミ骨上部構造を除去し，アブミ骨底板 に直径 $0.8 \mathrm{~mm}$ の小孔を開けたところ.

アブミ骨前脚拉よびアブミ骨筋腱の残存部分が確 認される。 
2 ).キヌタ・アブミ関節を外し，アブミ骨上 部構造を骨折除去したのち，アブミ骨底板に直 径 $0.8 \mathrm{~mm}$ の小孔を開け (図 3 ), 長さ $4.5 \mathrm{~mm}$ 直径 $0.6 \mathrm{~mm}$ の slim teflon wire and piston 小孔に挿入し, wire をキヌタ骨長脚に固定し た(図 4).小孔周囲とキヌタ骨に固定した wire 部分を筋膜で覆い，手術を修了した。術 後 2 力月目の会話域気導执よび骨導平均聴力レ ベルはそれぞれ $23.3 \mathrm{~dB}$ と $23.3 \mathrm{~dB}$ であり, 気導骨導差は消失した。

図 2 ４は術中に録画した立体ハイビジョン 映像を，デジタル画像処理システムによりデー タ変換し，直接印刷したものである。図の縦： 横比は 9:16で, 実際のハイビジョンの画面比 に等しい。手術中でももらろんテレビ画面を通 して手術の様子は立体視ができるが，ビデオの 再生画面，あるいはここに示したよらな印刷画 面も立体視でき, 平面での解像度をはるかた上 回った理解ができる。言うまでもないが，この 印刷のオリジナルはカラー印刷でめる。 カラー 印刷画像については，他に報告したので参照さ れたい1)。

\section{考察 \\ 耳科手術に始まったマイクロサージャリー,} すなわち顕微鏡下の手術は, 現在耳鼻咽喉科だ けでなく, 眼科, 脳神経外科, 整形外科, 形成 外科など多くの科で行われている. 双眼顕微鏡 を用いることで初めて中耳や内耳のよらな体表
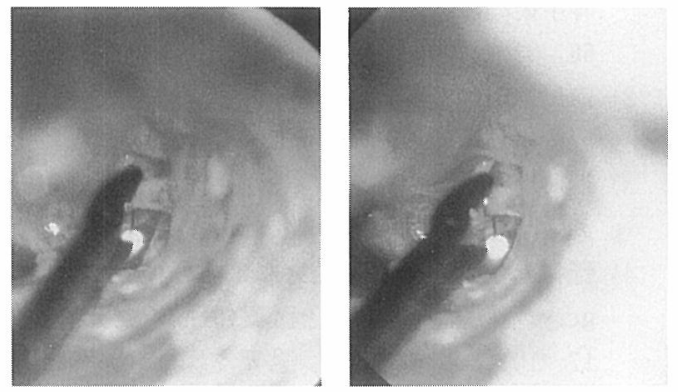

図 4 キヌタ骨長脚に長さ $4.5 \mathrm{~mm}$, 直径 0.6 $\mathrm{mm}$ の slim teflon wire and piston を固定 したところ。
面から深く入った部位の，しかも微細な構造物 の手術が可能になった。今や，耳科手術すなわ ち鼓室形成術やアブミ骨手術などの手術は，顕 微鏡下手術以外には考光られない。従って, 顕 微鏡下手術の教育, 特に卒後教育を如何に行う かが問題となる。そのために，死体側頭骨の顕 微鏡下手術解剖を行ったり, 顕微鏡の側視鏡を 用いた教育を行ったり，ビデオ撮影を行いなが ら手術を施行するなどの工夫が成されている。 しかし，手術時の側視鏡では本当の立体視はで きず，テレビ画面は平面であるといら久点があ る。実際，このような方法を行い，手術手技を 教育するにはかなりの時間を要する。何故なら， 平面やそれに近い状態から立体像を構築するの は, その人の頭衹解剖的立体像がすでにある 程度存在する必要があるからである。術者と同 じ視野と深度での手術供覧, すなわち 3 次元画 像が望まれる所以である.

ビデオの手術教育への利用は，多くの人が何 回でも見られるといら利点があり, 現在最も広 く用いられている.この場合，ビデオ画面が明 瞭であり，実際の場面を忠実に再現することが 望まれる. 現在本邦で用いられているビデオシ ステムは，NTSCであり走査線の数が525本で ある. ハード面の進歩で以前に比べ数段良いビ デオ画像が得られるようになったが，やはりそ れなりの限界があるのも事実である。この限界 を越光るものとして最近ハイビジョンが開発さ れ，その試験放送も行われるようになっている。 八イビジョンは走査線が1, 125本と NTSC 方式 に比べ倍以上の数があるため高品位画像が得ら れ，このような顕徴鏡下手術の記録には極めて 優れている223)。このため, 現在まで脳神経外 科や耳鼻咽喉科を始め多くの科でハイビショョン を用いた手術記録が試みられている4)5)。

今回は，先に述べた立体視のでさる画像を得 ることと, 高品位画像を得るとい5 2 つの要素 を組合わせた方法として，立体ハイビジョン撮 影を耳硬化症例で行った。その結果は，満足す べきものであった。すなわち，ハイビジョンを 
手術室で供覧したり録画をすることによって， それを見る人は術者とほとんど同じ解像度で観 察することが可能であった。このことは，こと に卒後教育，あるいは新しい手術手技の研究や 開発にも有用であると考えられる。また，静止 画像のデジタル変換による写真やスライドの作 成は，ビデオの供覧とともに広く他の人への伝 達方法として用いられるようになるものと想像 される.

ハイビジョンによる立体撮影は，すでに脳神 経外科6) 8) や耳鼻咽喉科9) でも行われているが, 最も最近の脳神経外科の報告10) 以前のものは, ハイビジョンカメラを 2 台用いた方式のもので あり，その重量などの点から実用には多少問題 が残った、しかし，今回用いたカメラは従来の もの $(6.5 \mathrm{Kg})^{3)}$ と比べ $1.9 \mathrm{Kg}$ と軽量であり耳 科手術のように顕微鏡の微妙な操作が必要なも のにも何ら支障を来すことはなかった. 今後こ の方式が広く用いられるよらになると思われる.

従来一般に用いられていた立体映像の撮影方 法は，2 台のカメラで撮影したものが主流であ り，偏光フィルターを使用した眼鏡方式10) と 液晶シャッター眼鏡を使用した時分割スイッチ 方式のいずれかの方式を用いて立体視を行って いる.このため, フィルターやシャッターによ って目に入る光量が变化するので長時間の観察 には無理が生じる.一方, 今回用いた方式では, 一台のカメラで撮影したものを一画面に表示し, それを立体視する方法を用いているので， 2 台 のカメラによる撮影のために付帯する問題点,

例えば $2 つ の$ 画面を同期させるために特殊な器 材が必要であるとか，先に述べたような立体視 が長時間できないなどの点はほぼ解消されてい る.

ハイビジョンの問題は, 現時点ではハイビジ ョン用のテレビカメラ，モニター，扎よび録画 ・再生装置が高価な点である。また， ハイビジ ョンシステム自体が開発途上であり, 汎用性が まだ十分でないための問題点がある.すなわち, 録画したビデオを供覧するにも，ハイビジョン
用のモニターと再生装置が必要となるからであ る.しかし, これらの点は近い将来, 解決され る問題であろら.

最後に，本報告で示したビデオ画面をそのま ま出力した印刷画面 (図 $2 \sim 4$ ) は, 平行法で立 体視をする人用に画面が配列されている．従っ て，交差法で立体視をする人では，実際の像と 凹凸が逆になって見觉るよらになっている，ど ちらの立体視法でも正しく立体視できるように， 簡単な操作で画面の左右が逆にできる方法が現 在考えられていることを付け加えて扣きたい。

\section{まとめ}

ハイビジョン立体撮影をアブミ骨手術例に用 い，その有用性について述べた．今回の立体撮 影方式は, 脳神経外科で最近用いられたのが本 邦で初めてであり，耳鼻咽喉科領域では今回の ものが初めての撮影になる.

ハイビジョンの解像度と, 立体といら 2 つの 要素を組合わせることによって，従来のビデオ 画像と比べはるかに優れた伝達能力を有してい ることが分った．本方式は，耳科手術の教育や， 手術手技の研究・開発に有力な手段となること が期待される.

\section{謝 辞}

本研究に協力いただいた望月 亮殿(国際メディア ・コーポレーション)に感謝します。

\section{文献}

1）八木聰明, 斉藤 博 : 八イビジョン立体撮影の 耳手術への応用. 耳喉頭頸目でるる耳鼻咽喉科 $66: 92 \sim 93,1994$.

2）赤川忠明 : 本格化するハイビジョンの医学・医 療応用. New Media 8 : 12 14, 1990.

3）福田輝文: ハイビジョン医学・医療応用のシス テム開発の課題. New Media $8: 27 \sim 29,1990$.

4）野村恭也：ハイビジョンによる耳の microsurgery. ハイビジョンと医療(医療研究会編). 17〜19頁，ハイビジョン普及支援センター，川 崎, 1990 .

5）編集部調査：ハイビジョン医学・医療応用手術 撮影画像利用事例. New Media $8: 15 \sim 17$, 
1990.

6）小林茂昭, 奥寺 敬, 竹前紀樹 : 脳神経外科手 術のハイビジョン立体撮影. New Media 8:18 $\sim 20,1990$.

7）奥寺 敬, 竹前紀樹, 京島和彦, 他 : 医学領域 に拉けるハイビジョンの可能性. 信州医誌 39 : 225〜232, 1991.

8) Okudera H, Kobayashi S, Takemae T, et al : Introduction of high definition television system to neurosurgical documentation. Neurol Res $14:$ 386 388, 1992.
9）加我君孝, 原 誠, 中村直也：先天性中耳奇 形「アブミ骨筋腱の骨化症の 1 例」. Otol Jpn $2: 495,1992$.

10）奥寺 敬, 小林茂昭, 望月 亮, 他: ハイビジ ョンによる脳神経外科䫓微鏡下手術の立体撮影. コンピュータ外科 $2: 13 \sim 14,1993$.

$\left(\begin{array}{l}\text { 原稿受付 : 平成 } 5 \text { 年 } 11 \text { 月 } 25 \text { 日 } \\ \text { 原稿採択 : 平成 } 5 \text { 年 } 12 \text { 月 } 15 \text { 日 } \\ \text { 別刷請求先 : 八木聰明 } \\ \text { †113 東京都文京区千駄木 } 1-1-5 \\ \text { 日本医科大学耳鼻咽喉科学教室 }\end{array}\right)$ 